\title{
THE BIOCHEMICAL ALTERATION AND DNA DAMAGE IN RATS (RATTUS RATTUS) AFTER CHRONIC INTRAPERITONEALLY INJECTION TO PURIFIED MICROCYSTIN-LR FROM ANABAENA CIRCINALIS
}

\author{
MAHER M KHADAIRI*, MOAYED JY AL-AMARI, AYAD MJ AL-MAMOORI \\ Department of Biology, College of Science, University of Babylon, Hillah, Iraq. Email: ayad@uobabylon.edu.iq \\ Received: 11 June 2017, Revised and Accepted: 31 July 2017
}

ABSTRACT

Objective: This study determined the effect of purified microcystin-leucine arginine (MC-LR) on biochemical and DNA damage parameters in rats.

Methods: Utilization of preparative high-performance liquid chromatography in analysis, purification and collection of MC-LR, then intraperitoneally injection of purified MC-LR to rats. At the end of exposure, animals were sacrificed, and liver cell was isolated to measure the biochemical markers such as superoxide dismutase (SOD), catalase (CAT) and glutathione (GSH) as well as measured malondialdehyde (MDA), reactive oxygen species (ROS) and cytochrome P450 (Cyt P450), and DNA damage markers such as comet length, tail length, and tail moment were measured with the single cell gel electrophoresis also called comet assay.

Results: The present results showed significantly increased activities of SOD as well as concentration of MDA, ROS with increasing concentration of MC-LR but the activities of CAT and GSH, as well as Cyt P450, were significantly decreased with increasing MC-LR dose while makers of DNA damage such as comet length, tail length, and tail moment also significantly increased with increasing MC-LR dose.

Conclusion: This study demonstrated that chronic exposure to MC-LR toxin can induce alteration of biochemical and DNA damage markers.

Keywords: Cyanobacteria, Purification, Microcystin-leucine arginine, Biochemical markers, DNA damage markers.

(c) 2017 The Authors. Published by Innovare Academic Sciences Pvt Ltd. This is an open access article under the CC BY license (http://creativecommons. org/licenses/by/4. 0/) DOI: http://dx.doi.org/10.22159/ajpcr.2017.v10i11.20565

\section{INTRODUCTION}

Microcystins (MCs) are hepatotoxins with cyclic peptides that contain seven amino acid linked by peptide bonds in the configuration of cyclic. The variants of different MC has been formed mainly because the $\alpha$-amino acids variations that are founding at positions two and four; for example, in MC-LR stands for leucine (L) and arginine (R) and a molecular weight of MC was ranged between 800 and 1000 daltons, its soluble in water and can't be able to cross through lipid membrane of animals, plants and bacteria and also its resistant to temperature, chemical hydrolysis, and oxidation [1]. MCs are known to effect on many organisms, from microorganism to mammals [2]. MCs can produce by different genera of Cyanobacteria such as Anabaena, Nostoc, Planktothrix, and Microcystis [2]. The World Health Organization has been determined acceptable of the maximum limit of MC-LR in drinking water was $1 \mu \mathrm{g} \mathrm{L-1}$ and for foods was $0.04 \mu \mathrm{g} \mathrm{kg-1}$ day- 1 consider as tolerance daily intake of MCs [3]. Cyanobacteria produce various metabolites that are antibacterial, antifungal, antimalarial, anticancerous, and antitumor [4,5].

The MC-LR can effect at molecular level, the major targets of MCs-LR are inhibition of serine-threonine protein phosphatases (PP). Inhibition of PP can stimulate through increasing proteins phosphorylation, that leads to disrupt of the microfilament of cytoskeleton and cell shape loss that can cause the liver cell destruction, which may lead to intrahepatic hemorrhage or liver failure [6].

The ability of MCs to generate oxidative stress can lead to increase the generation of reactive oxygen species (ROS) and oxidative damage, such as lipid peroxidation and the DNA damage $[6,7]$. The ROS are scavenging by the defense of antioxidant system which are antioxidant enzymes such as superoxide dismutase (SOD), catalase (CAT), glutathione (GSH) peroxidase and GSH reductase, and non-enzymatic antioxidants such as reduced GSH [8]. When the antioxidant defense has not enough to remove the ROS or ROS are produced in a large quantity, they can stimulate oxidative damage resulting in lipid peroxidation, chromosome aberration and induce DNA damage through the 8-oxo-deoxyguanosine formation (8-oxo-dG) consider as a marker of oxidative DNA damage [9].

\section{METHODS}

\section{Culturing of Anabaena circinalis}

Uni-algae of Anabaena sp. were obtained from University of Baghdad and take of $10 \mathrm{ml}$ of isolate of $A$. circinalis in log phase which added to a flask contained $90 \mathrm{ml}$ of BG11 media and incubated at $27 \pm 2^{\circ} \mathrm{C}$ with a photo period of 8 hrs darks: 16 hrs lights for 14 days, this flask that contained $100 \mathrm{ml}$ growth of $A$. circinalis would transport to flask contained $900 \mathrm{ml}$ of media and incubated for 14 days and ultimately the growth of $A$. circinalis in the flask that contained $1000 \mathrm{ml}$, would be transported to pools $15 \mathrm{~L}$ and harvested after 3-5 days at stationary phase (MC-LR was formed in this phase) and concentrated by centrifugation at $3000 \mathrm{rpm}$ for 15 minutes and lyophilized by oven at $35^{\circ} \mathrm{C}$ for $48 \mathrm{hrs}$, repeated culturing of each species of Anabaena sp. 4 time to obtain large amount of biomass [10].

\section{Extraction and purification of MC-LR}

Animal ethical approval: All procedures performed in studies involving animal were in accordance with the Ethical Standards of the Institutional and/or National Research Committee and with the 1964 Helsinki Declaration and its later amendments or comparable ethical standards. The $A$. circinalis cell are freeze-thaw, 3 times before extraction to disrupt the cell wall leads to easy release of MC from cell and lyophilized cell of $5 \mathrm{~g}$ from Anabaena sp. had been extracted 3 times by solvent mixture of water:methanol:1-butanol 75:20:5 for $1 \mathrm{hr}$ then sonication by path sonicator for $2 \mathrm{hr}$ and the extracts were centrifuged at $15,000 \mathrm{rpm}$ for 30 minutes at $20^{\circ} \mathrm{C}$, and the supernatant has been combined. The combined of supernatants would be air-dried at $35^{\circ} \mathrm{C}$ to remove methanol and 1-butanol and to concentrate to $3 \mathrm{ml}$ and MCs 
in each extract detected using ultraviolet (UV)-spectrophotometer at $238 \mathrm{~nm}[11]$.

The purification of toxins has been performed according to Tredici [11] above extract was loaded on glass column $(2 \mathrm{~cm} \times 15 \mathrm{~cm})$ which contained silica gel (75-250 mesh), then the column washed by $120 \mathrm{ml}$ of deionized water then followed by adding $20 \%$ of methanol and finally, the toxins had been eluted by adding $80 \%$ of methanol with flow rate $3 \mathrm{ml} /$ minutes.

\section{Analytical, purification and collection of MC-LR}

The toxins fraction has been dissolved in absolute methanol specialized for preparative high-performance liquid chromatography (HPLC) and $0.25 \mathrm{ml}$ was injected by microsyringe to PHPLC (type Shimadzu at Ministry of Science and Technology in the Department of Laboratory of Water and Environmental Analysis Test) have the following characters C18-Octanoldodecyl column with $25 \mathrm{~cm} \times 4.6 \mathrm{~mm}$ l.D and mobile phase (Methanol: $\left.\mathrm{H}_{2} \mathrm{O}\right)$ 20:80, flow rate $(1 \mathrm{ml} /$ minute) at wave length $238 \mathrm{~nm}$ and at $30^{\circ} \mathrm{C}$ of temperature [12]. The results compared with an absorbance and retention time of standard MC-LR was purchased from Sigma-Aldrich Company, then the peak of MC-LR was collected.

\section{Experimental designs}

The weight of male rats was $200 \pm 20 \mathrm{~g}$ purchased from Samarra province; the animals were handled following the guidelines in the Slovenian Law for Animal Health Protection and Instructions for Granting Permit for Animal Experimentation for Scientific Purposes. The rats were housed under controlled conditions of $12 \mathrm{hrs}$ light/ dark cycle, $50 \pm 5 \%$ humidity and $23 \pm 1^{\circ} \mathrm{C}$, the animals were allowed for 1 week to acclimate and free access to food (pellet) and tap water. Number of rats for experimental were 40 individual, divide into two group, each group include 20 rats and subdividing into eight group, put in each groups six individuals of rats for acute and five individual for chronic exposures, the control group was intraperitoneal injected by distal water, and treatment groups were intraperitoneal injected to different concentration of MC-LR $(3,6,9) \mu \mathrm{g} / \mathrm{kg} /$ day for 30 days as chronic exposure [13].

\section{Antioxidants defense}

Activity of SOD has been measured by autoxidation of pyrogallol according to Qiu et al. [14]. While CAT activities were determined according to the procedure of Marklund and Marklund [15] but activity of GSH was determined according to the method of Claiborne [16]. The acid soluble sulfhydryl groups form a yellow colored complex with dithio nitrobenzene.

\section{Lipid peroxidation, ROS, and cytochrome P450 (Cyt P450)}

Lipid peroxidation had been estimated by the assay of thiobarbituric acid for malondialdehyde (MDA) concentration according to Moreno et al. [17] and Aust [18]. Whereas ROS and Cyt P450 were determined according to ELISA kit of Elabscience, China.

\section{DNA damage}

Taken a small portion of liver tissue (50 $\mathrm{mg}$ ) is serially washed and this piece of liver is placed in $2 \mathrm{ml}$ microcentrifuge tube containing $1.5 \mathrm{ml}$ of phosphate buffer solution then homogenization by homogenized $(15-20 \mathrm{~s})$ by pestle motor mixer, then added $40 \mu \mathrm{l}$ of proteinase $\mathrm{K}$ liver tissue to remove protein and centrifugation at $13,000 \mathrm{rpm}$ for 15 minutes, $4^{\circ} \mathrm{C}$, taken $2-5 \mu \mathrm{l}$ of suspension cell to a clean $1.5 \mathrm{ml}$ tube and mix on comet slide with $40 \mu$ lof low melting agarose, then prepare lysis solution that consist of $2.5 \mathrm{M} \mathrm{NaCl}, 100 \mathrm{mM}$ EDTA, $10 \mathrm{mM}$ Trisbase, and $8 \mathrm{~g} \mathrm{NaOH}$, all dissolved and complete to $700 \mathrm{ml}$ deionized water, then added $110 \mathrm{ml}$ from $55 \mathrm{ml} 1 \%$ Triton X to $55 \mathrm{ml} \mathrm{10 \%} \mathrm{dimethyl}$ superoxide after that complete the volume to $100 \mathrm{ml}$ by deionized water and before use, chill at $4^{\circ} \mathrm{C}$ or on ice for at least 20 minutes and combine $7.5 \mu \mathrm{l}$ with $75 \mu \mathrm{l}$ low melting agarose and immediately spread the mix onto the clear part of a comet slide, then warm comet slide on a heating plate at $42-50^{\circ} \mathrm{C}$ before application to prevent permit evenly spreading of the agarose and prevent the formation of air bubbles, slides may be stored in lysis solution at $4^{\circ} \mathrm{C}$ for 60 minutes after that removing the lysis solution and replace by alkaline solution contain $6 \mathrm{~g} \mathrm{NaOH}$ and $500 \mu \mathrm{l} 0.5 \% \mathrm{Na}_{2}$ EDTA for 5-60 minutes at room temperature in dark, then removing slide from alkaline solution gently tap excess buffer from slide and washed by immersing in $1 \mathrm{X}$ TBE buffer for 5 minutes, after that, transferred slide from 1X TBE buffer to an horizontal electrophoresis apparatus and place slides on flat of gel tray and pour $1 \mathrm{X}$ TBE buffer until to cover the slides for 60 minutes vol 70, then very gently tap off excess TBE and added some drops of $70 \%$ ethanol on slides to remove the water, and stain the slides by ethidium bromide then leave the slides for $24 \mathrm{hrs}$ and view slide by fluorescence microscope [19] with modification by Singh et al. [20].

\section{Statistical analysis}

Data of present study were analyzed according to the system of Statistical Package for the Social Sciences (SPSS) version 20 to found means, least significant differences by ANOVA.

\section{RESULTS}

\section{Extraction and purification of MC-LR}

The extraction of $A$. circinalis has been extracted by water:methanol:butanol and partially purified by silica gel column, then analyzed by preparative HPLC to detect the present of MCLR and concentration of toxin was determined by comparing peak area and retention time of analytical standard of MC-LR with peak area and retention time of extraction of Anabaena sp., the retention time of analytical standard of MC-LR was 9.55 minutes (Fig. 1): And it's concentration was $10 \mu \mathrm{g} / \mathrm{ml}$ and A. circinalis retention time was 9.51 minutes (Fig. 2): And it's concentration was $74.832 \mu \mathrm{g} / \mathrm{ml}$, then highly purified and collected of MC-LR by preparative HPLC.

\section{Biochemical markers}

The statistical analysis shown significant differences in all biochemical marker among control and treatments at $\mathrm{p}<0.05$, the SOD activity in liver tissue control was $2.2 \mathrm{U} / \mathrm{mg}$. While the activity of SOD in treated liver tissue was $6.1,32.8$, and $12.4 \mathrm{U} / \mathrm{mg}$ in doses 3,6 , and $9 \mu \mathrm{g} / \mathrm{kg}$ body weight (b.w.) In liver tissue control (Table 1 and Fig. 3): CAT activity was $28.8 \mathrm{U} / \mathrm{mg}$, whereas in treated liver, the activity of CAT was reached to 132 and $40.1 \mathrm{U} / \mathrm{mg}$ in doses 3 and $6 \mu \mathrm{g} / \mathrm{kg}$ b.w., respectively, while CAT activity in doses $9 \mu \mathrm{g} / \mathrm{kg}$ b.w. has been decreased to $24.7 \mathrm{U} / \mathrm{mg}$ as compared with control groups (Table 1 and Fig. 4): GSH activity in control of liver tissue was $78.5 \mu \mathrm{mol} / \mathrm{ml}$, while GSH activity in liver tissue was decreased $68.8,72.7$, and $75.4 \mu \mathrm{mol} / \mathrm{ml}$ in doses 3,6 , and $9 \mu \mathrm{g} / \mathrm{kg}$ b.w. as compared with control (Table 1 and Fig. 5).

MDA concentration of control was $0.86 \mu \mathrm{mol} / \mathrm{ml}$ in liver, while the MDA concentration significantly increased in three doses 6.19, 9.45, and $13.6 \mu \mathrm{mol} / \mathrm{ml}$ in liver tissue (Table 1 and Fig. 6). Whereas, the ROS concentration reached in control to $14.9 \mathrm{p} / \mathrm{ml}$ in liver tissue while ROS concentration in three doses were 206, 299.8, and $394.9 \mathrm{p} / \mathrm{ml}$ in treated liver (Table 1 and Fig. 7). The Cyt P450 concentration in control was $1013.5 \mathrm{p} / \mathrm{ml}$ in liver tissue, but it's concentration in the treatment was significantly decreased to $861 \mathrm{p} / \mathrm{ml}$ in dose $3 \mu \mathrm{g} / \mathrm{kg}, 614.8 \mathrm{p} / \mathrm{ml}$ in dose $6 \mu \mathrm{g} / \mathrm{kg}$, and $434.4 \mathrm{p} / \mathrm{ml}$ in dose $9 \mu \mathrm{g} / \mathrm{kg}$ in treated liver tissue (Table 1 and Fig. 8).

\section{DNA damage markers}

The DNA damage markers were showed significant differences between control and treatments according to statistical analysis at $p<0.05$. The comet length scored highest levels in rats at dose $9 \mu \mathrm{g} / \mathrm{kg}$ b.w. that are $312.5 \mu \mathrm{m}$ (Fig. 9). Whereas tail length was recorded the highest levels at dose $9 \mu \mathrm{g} / \mathrm{kg}$ b.w. that have reached to $97.42 \mu \mathrm{m}$ (Fig. 9). While the highest levels that were observed in tail moments in rats was $85.07 \mu \mathrm{m}$ at dose $9 \mu \mathrm{g} / \mathrm{kg}$ b.w. (Fig. 9). According to pictures were taken, the DNA damage can be classified into three class of damage that is Class 1: Low damage, Class 2: Medium damage, and Class 3: High damage in liver of rats (Fig. 10). 
Table 1: The biochemical markers in the liver of rat during chromic exposure period to MC-LR mean \pm SD

\begin{tabular}{lllll}
\hline Biochemical markers & Control & $\mathbf{3} \boldsymbol{\mu g} / \mathbf{k g}$ b.w. & $\mathbf{6} \boldsymbol{\mu g} / \mathbf{k g}$ b.w. & $\mathbf{6} \boldsymbol{\mu g} / \mathbf{k g}$ b.w. \\
\hline SOD U/mg & $2.2 \pm 0.043$ & $6.1 \pm 1.033$ & $23.75 \pm 3.782$ & $12.35 \pm 1.132$ \\
CAT U/mg & $28.8 \pm 2.453$ & $132.48 \pm 21.760$ & $40.08 \pm 1.320$ & $24.72 \pm 3.672$ \\
GSH $\mu \mathrm{mol} / \mathrm{ml}$ & $78.46 \pm 3.440$ & $68.76 \pm 5.401$ & $72.66 \pm 10.234$ & $75.4 \pm 12.675$ \\
MDA $\mu \mathrm{mol} / \mathrm{ml}$ & $0.86 \pm 0.001$ & $6.19 \pm 0.532$ & $9.45 \pm 0.895$ & $13.6 \pm 1.006$ \\
ROS p/ml & $14.85 \pm 0.456$ & $206.34 \pm 17.120$ & $298.85 \pm 22.136$ & $393.57 \pm 11.289$ \\
Cyt p $450 \mathrm{p} / \mathrm{ml}$ & $1035.13 \pm 34.78$ & $861 \pm 110.32$ & $614.84 \pm 5.435$ & $434.36 \pm 6.98$ \\
\hline
\end{tabular}

SOD: Superoxide dismutase, CAT: Catalase, GSH: Glutathione, MDA: Malondialdehyde, ROS: Reactive oxygen species, SD: Standard deviation, Cyt p450: Cytochrome p450, MC-LR: Microcystin-leucine arginine, b.w.: Body weight

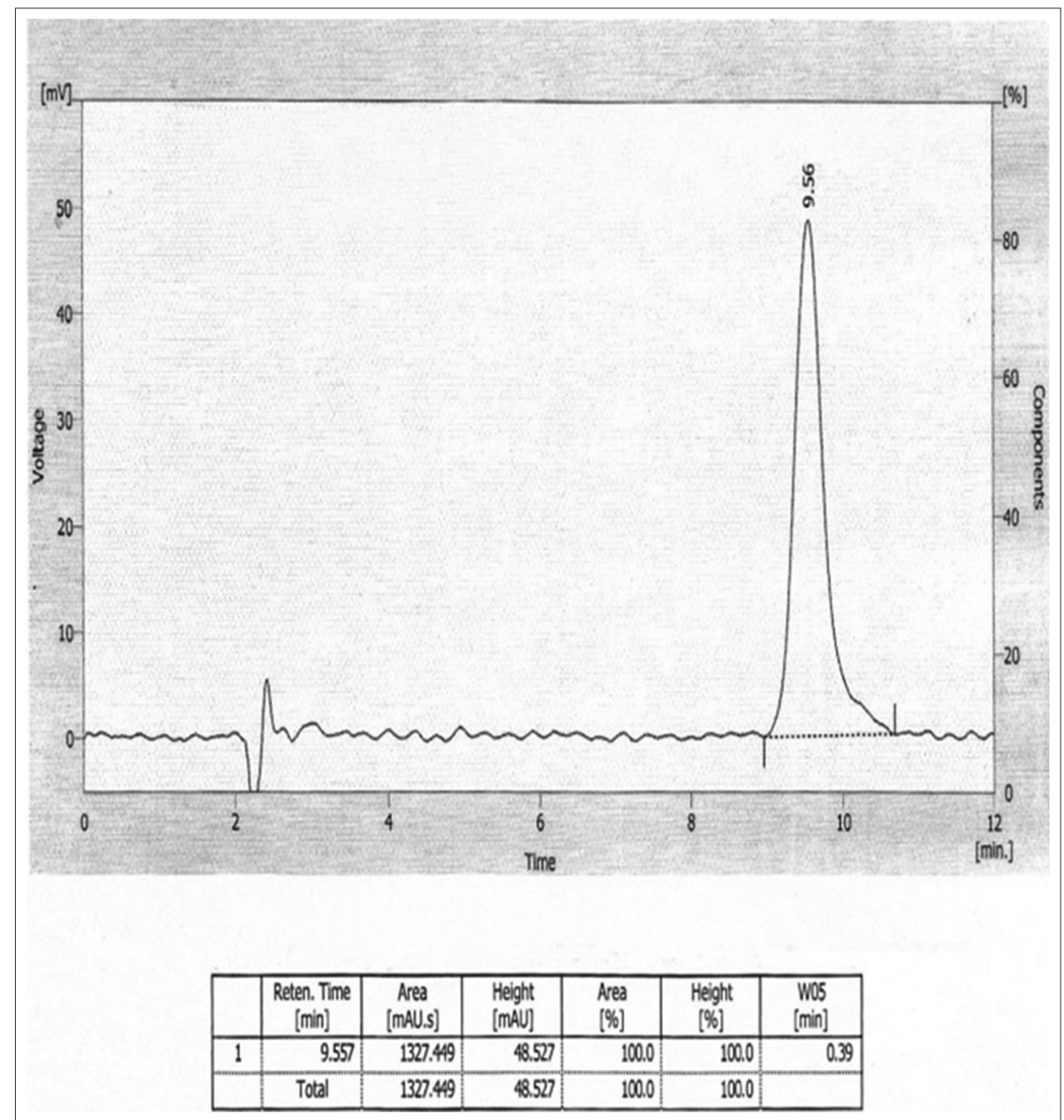

Fig. 1: Peak of microcystin-leucine arginine standard that used in study, analyzed by preparative high-performance liquid chromatography

\section{DISCUSSION}

Extraction, separation, and purification of MC-LR

Cyanobacterial toxins are intracellular toxins that are released to medium by breaking Cyanobacterial cell or die so that Cyanobacteria was needed solvents for extraction Cyanotoxins. In this study, the solvent used in extraction of MC-LR was water:methanol:butanol (75:20:5) because of efficiencies of extraction of different structure variant of MC were increased with their hydrophobicity ,[21,22] shown that the polar extracts (water: methanol:butanol) have higher contents of MC because of MC polarity, therefore, MCs are soluble in water:methanol:butanol.

MCs variants require high resolution for separation and purification, which depends on the mobile phase composition and stationary phase that is used in analysis [12]. In this study, silica gel column was used and elution by $80 \%$ methanol to partial separation of MC and then highly purified and collected MC-LR from A. circinalis by PHPLC at $238 \mathrm{~nm}$ absorbance of MCs because of strong absorbance of MC at $238 \mathrm{~nm}$ enabling sensitive UV detection due to the main chromophore of the toxins can absorb at $238 \mathrm{~nm}$ is the conjugated diene in the adda residue [23].

\section{Biochemical markers}

The results of presents were showed that the SOD activities significantly increased with increasing dose of MC-LR, SOD plays essential role in converting superoxide anion radical produced in body to hydrogen peroxide [24]. This result agreed with study by Sicinska et al. [25] reported increased SOD activity induces by 


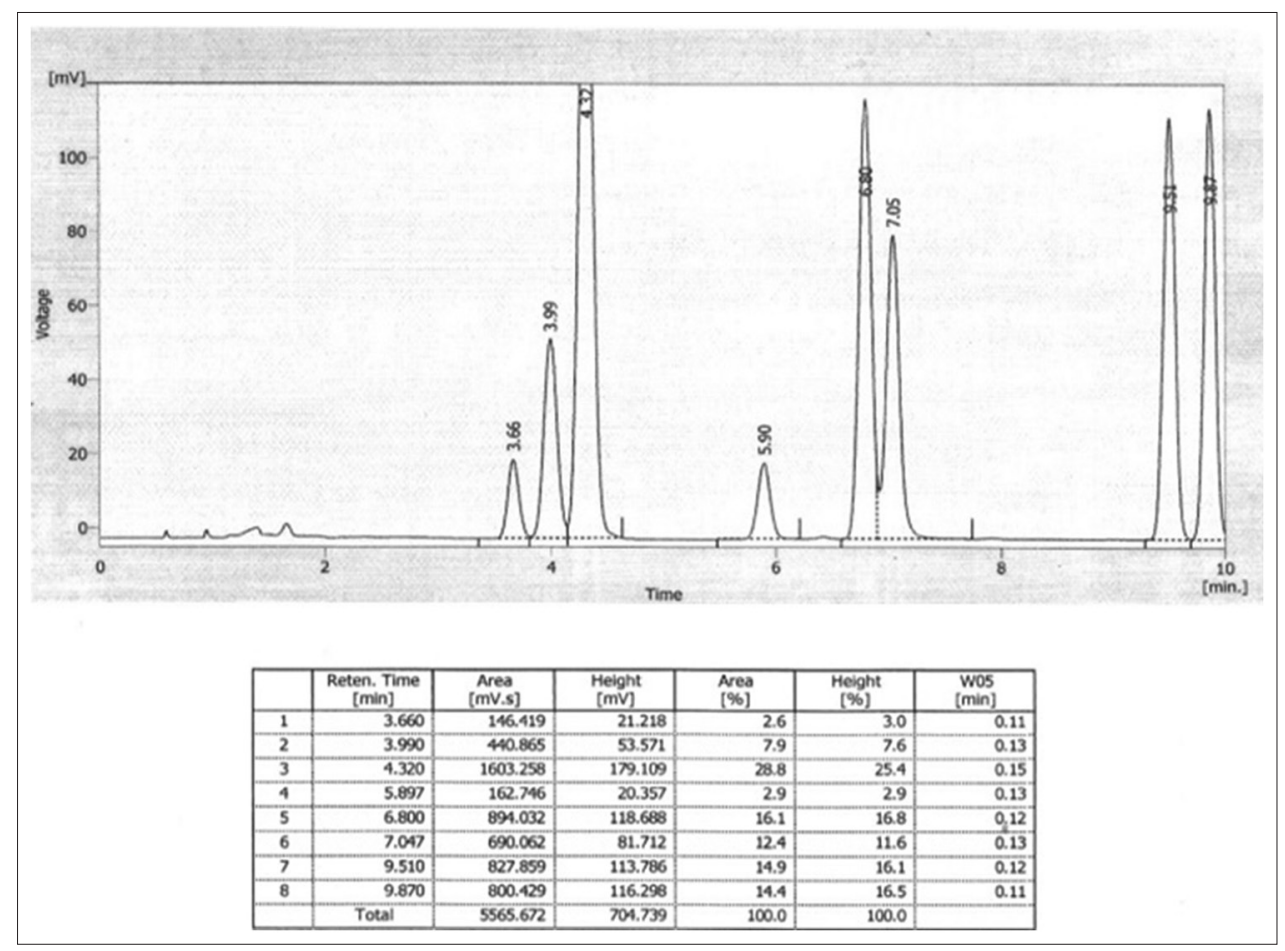

Fig. 2: Chromatography of preparative high-performance liquid chromatography at absorbance $238 \mathrm{~nm}$ for Anabaena circinalis

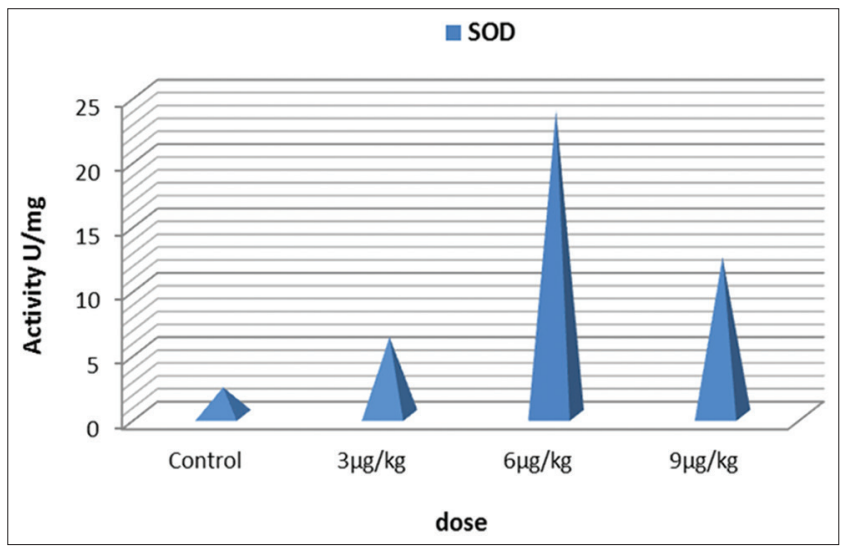

Fig. 3: Superoxide dismutase activities in liver of rats after chronic exposure period by purified microcystin-leucine arginine

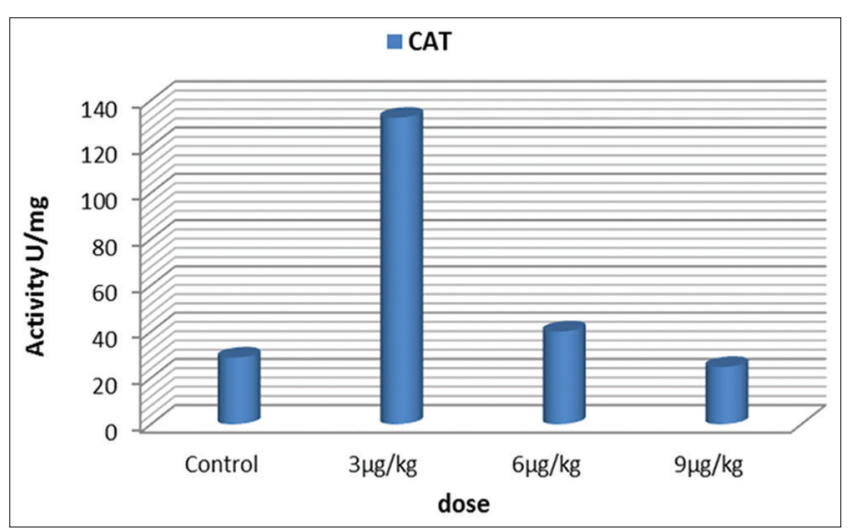

Fig. 4: Catalase activities in liver of rats after chronic exposure period by purified microcystin-leucine arginine

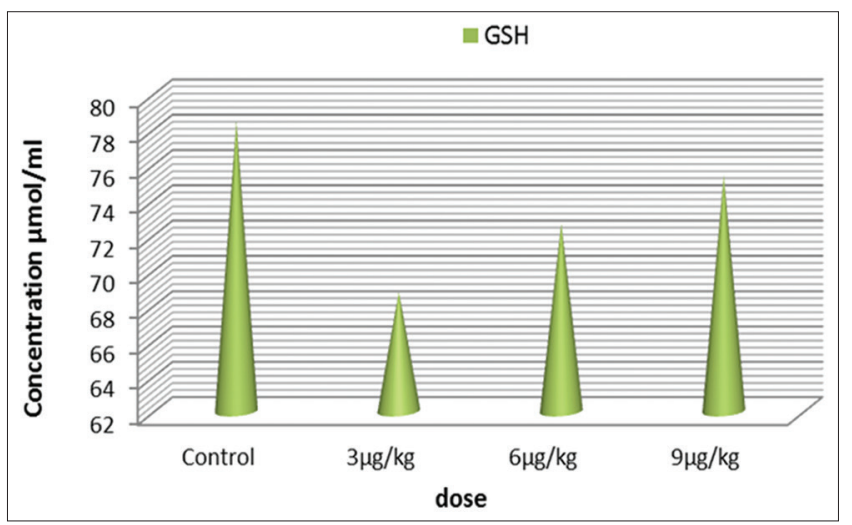

Fig. 5: Glutathione concentration in liver of rats after chronic exposure period by purified microcystin-leucine arginine

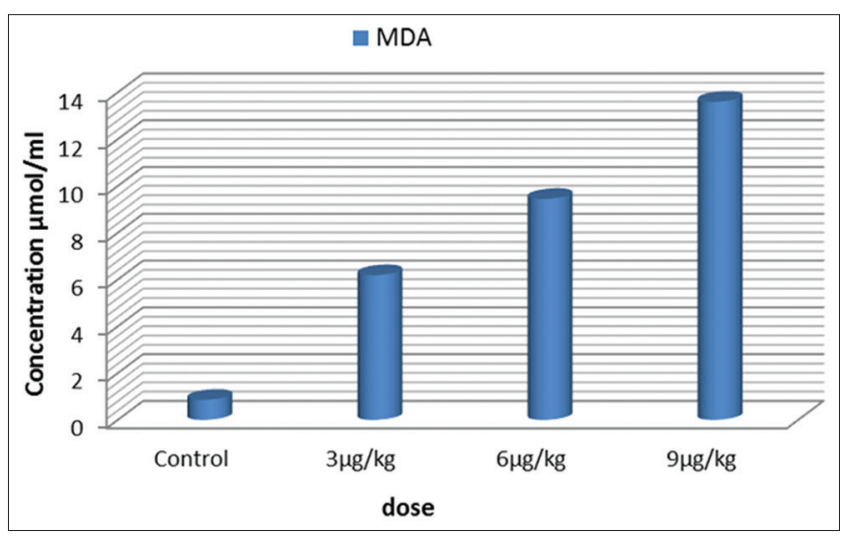

Fig. 6: Malondialdehyde concentration in liver of rats after chronic exposure period by purified microcystin-leucine arginine 


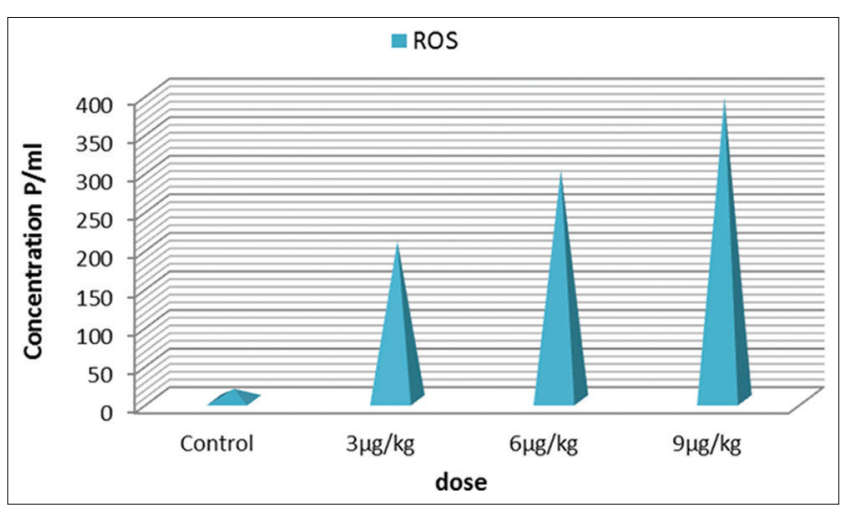

Fig. 7: Reactive oxygen species concentration in liver of rats after chronic exposure period by purified microcystin-leucine arginine

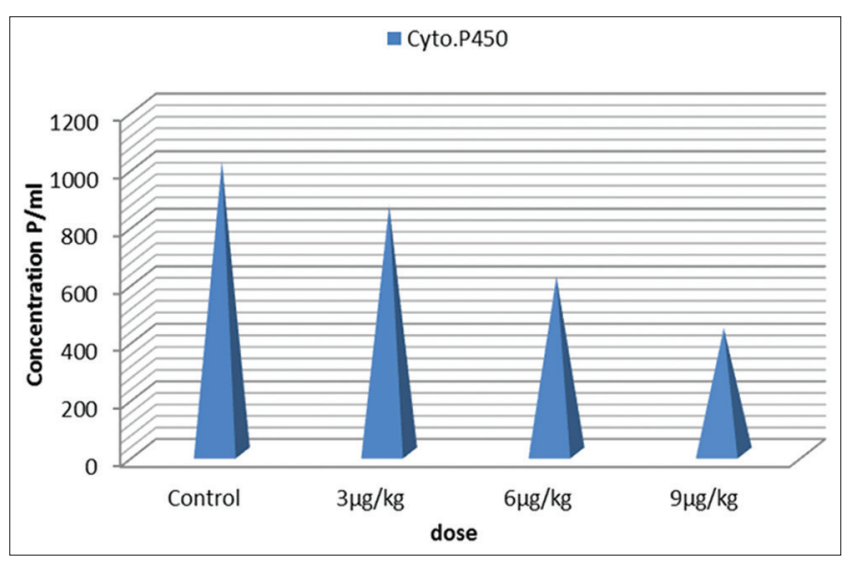

Fig. 8: Cytochrome p450 concentration in liver of rats after chronic exposure period by purified microcystin-leucine arginine

MC-LR. In contrary with Harada [24] study demonstrated MC-LR can decrease the SOD activity and increase lipid peroxidation. While CAT activity significantly decreased with increasing concentration of MC-LR, CAT is localized in subcellular peroxisomes where convert hydrogen peroxide to water and molecular oxygen, CAT activity decreased may be due to either direct damage to structure of protein or increased the level of superoxide anion radical [26]. GSH which is the main compound in the intracellular redox status regulation and it's considered as essential cofactor in many metabolic reactions [27]. The results of this study, observed significant decrease of GSH in liver of rats may be due to a compensatory response induce by imbalance in the cell redox state as the result of excessive $\mathrm{H}_{2} \mathrm{O}_{2}$ production or may be related to its involvements in detoxification of deleterious effects of the increase free radical produce within cells $[17,28,29]$. Demonstrated that exposure of rats to MC-LR resulted in an increase of the endogenous antioxidant defense system together with an increase of lipid peroxidation in liver and in the kidney. The MDA and ROS concentration significantly elevated with increasing concentration of MC-LR due to MC-LR induced oxidative stress that occurs through an imbalances between the rate of production of ROS and the rate of removal of these ROS by antioxidants defense systems [30]. The studies that are reported the MC-LR ability to induce the ROS formation that lead to oxidative stress and lipid peroxidation in many organisms such as rats [16].

Cyt P450 belong to a superfamily of heme monooxygenase that is catalyzed oxidation of lipid, steroidal hormones and numerous xenobiotic chemicals such as drug, carcinogen and environmental pollutants, and the Cyt P450 that are involved in metabolizing endogenous substance and biotransformation of MCs through converting from lipophilic into less toxic hydrophilic [31]. These

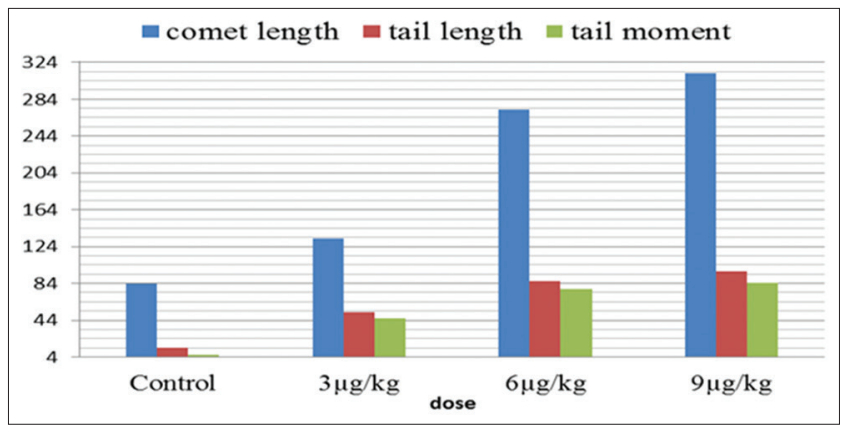

Fig. 9: The criteria of DNA damage in liver of rats after chronic exposure period by purified microcystin-leucine arginine according to comet assay
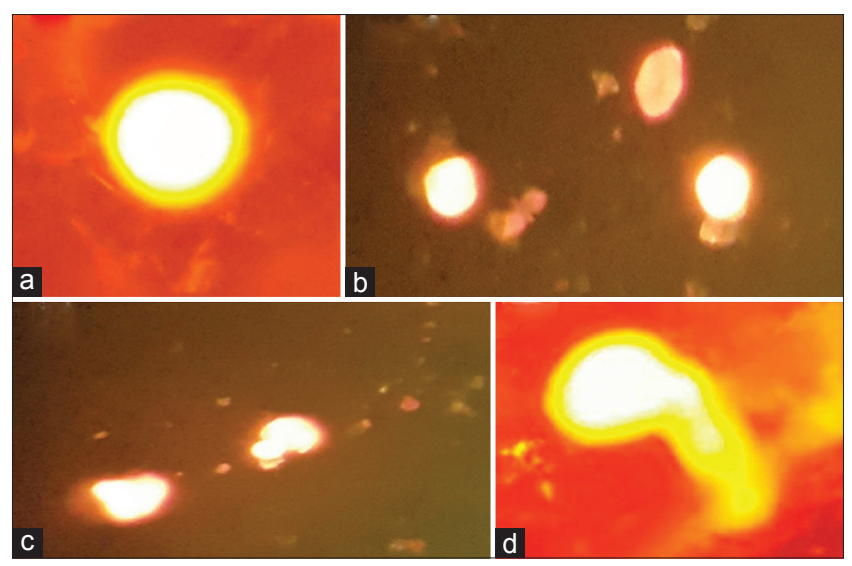

Fig. 10: DNA damage in the liver of rats according to comet assays. (a): Control, (b): Low damage, (c): Medium damage, and (d): High damage $(\times 40)$

results of presents study were showed in chronic period, the Cyt P450 concentration in liver of rats was significantly decreased due to Cyt P450 activity was changed can reflect the presence of MC-LR lead to alter the Cyt P450 expression or enzyme activity in various organism and Cyt P450 activity decreased via increasing the ROS formation [32-34]. The study reported by Zhang et al. [35] showed that MC-LR induced decreased the level of cytochrome b5 and Cyt P450 liver of rats during period. While in another study was showed that Cyt P450 activity change that induces by MC-LR in zebrafish and mice [36,37]. This study corresponding with [38] testing the adverse effect of purified MC on mouse liver have found that MC-LR is 30-100 times less toxic via oral ingestion than via intraperitoneal injection, also antioxidant such as SOD, CAT and ROS and MDA increased with increasing period of exposure, and concentration of MC-LR, while GSH and Cyt P450 decrease due to oxidative stress.

\section{DNA damage}

DAN damage occurred by MC-LR through the involvement of ROS that leads to oxidative stress, via mitochondrial permeability transition and cytoskeleton disruption DNA strand breaks and DNA oxidized bases products of free radical attack that are stimulating by MCs [39].

MC-LR had been induced DNA damage in liver cell in vivo and in vitro through the formation 8-oxo-dG, and DNA lesions are used as markers for oxidative DNA damage [40]. The DNA damage that induces by MC-LR can be related with apoptosis rather than with genotoxicity [41] while Lankoff [42] also demonstrate MC-LR induce DNA damage and genotoxicity through its ability to cause genetic instability in erythrocytes in bone marrow of mice injected $45 \mu \mathrm{g}$ MCLR/kg bw for $24 \mathrm{hrs}$ and MC-LR stimulate a 2 -fold increase 
in the level of DNA damage in blood cell after 30 minutes of i.p. injection $(37.5 \mu \mathrm{g} \mathrm{MCLR} / \mathrm{kg} \mathrm{bw})$ of rats.

The result of presents study had been showed, the parameters of comet assay were significantly differences between treatment and control group, the highest values of comet length $\mu \mathrm{m}$, tail length $\mu \mathrm{m}$, and tail moment $\mu \mathrm{m}$ in liver of rats were recorded at dose $9 \mu \mathrm{g} / \mathrm{kg}$ b.w. as compared with control group, the statistical analysis appeared positive significant correlation between DNA damage markers and the dose of MC-LR, biochemical markers. The comet length was positively correlated with the level of DNA breakage in cell because the distribution the comet was heterogeneous [19]. The highest value of the markers of DNA damage would be increased with increasing the toxicant dose this may be due to insufficient produce of antioxidant defense systems to scavenge the ROS that is generated by MC-LR which lead to finding their way across nuclear membrane indicating DNA strand breakage [42-46].

\section{REFERENCES}

1. Amado LL, Monserrat JM. Oxidative stress generation by microcystins in aquatic animals: Why and how. Environ Int 2010;36(2):226-35.

2. Atencio L, Moreno I, Jos A, Pichardo S, Moyano R, Blanco A, et al. Dose-dependent antioxidant responses and pathological changes in tenca (Tinca tinca) after acute oral exposure to Microcystis under laboratory conditions. Toxicon 2008;52(1):1-12.

3. WHO. Blue-Green Algae in Inland Waters: Assessment and Control of Risks to Public Health. Geneva: World Health Organization (WHO) Document, Annex G; 1998.

4. Kumar M. Harvesting of valuable eno-and exo-metabolites from cyanobacteria: A potential source. Asian Pharm Clin Res 2014;2:974-2441.

5. Naseri A, Karami M, Nadoushan MJ. Failing of information transmission by dorsal hippocampus due to microinjection of colchicine in rats cortical area 1. Asian Pharm Clin Res 2015;4:974-2441.

6. Campos A, Vasconcelos V. Molecular mechanisms of microcystin toxicity in animal cells. Int J Mol Sci 2010;11(1):268-87.

7. Zegura B, Sedmak B, Filipic M. Microcystin-LR induces oxidative DNA damage in human hepatoma cell line HepG2. Toxicon 2003;41(1):41-8.

8. Pinho GL, da Rosa CM, Maciel FE, Bianchini A, Yunes JS, Proença LA, et al. Antioxidant responses and oxidative stress after microcystin exposure in the hepatopancreas of an estuarine crab species. Ecotoxicol Environ Saf 2005;61(3):353-60.

9. Livingstone DR. Contaminant-stimulated reactive oxygen species production and oxidative damage in aquatic organisms. Mar Pollut Bull 2001;42(8):656-66.

10. Bouaicha N, Maatouk I, Plessis MJ, Perin F. Genotoxic potential of microcystin-LR and nodularin in vitro in primary cultured rat hepatocytes and in vivo in rat liver. Environ Toxicol 2005;20(3):341-7.

11. Tredici MR. Mass production of microalgae: Photobioreactors. In: Richmond A, editor. Handbook of Microalgae Culture: Biotechnology and Applied Phycology. Oxford: Blackwell Science; 2004.

12. Namikoshi M, Choi BW, Sun F, Rinehart KL, Evans WR, Carmichael WW. Chemical characterization and toxicity of dihydro derivatives of nodularin and microcystin-LR, potent cyanobacterial cyclic peptide hepatotoxins. Chem Res Toxicol 1993;6(2):151-8.

13. Lawton LA, Edwards C. Purification of microcystins. J Chromatogr A 2001;912(2):191-209.

14. Qiu T, Xie P, Liu Y, Li G, Xiong Q, Hao L, et al. The profound effects of microcystin on cardiac antioxidant enzymes, mitochondrial function and cardiac toxicity in rat. Toxicology 2009;257(1-2):86-94

15. Marklund S, Marklund G. Involvement of the superoxide anion radical in the autoxidation of pyrogallol and a convenient assay for superoxide dismutase. Eur J Biochem 1974;47(3):469-74.

16. Claiborne A. Catalase activity. In: Greenwald RA, editor. CRC Handbook of Methods for Oxygen Radical Research. Boca Raton, FL: CRC Press; 1985. p. 283-4.

17. Moreno I, Pichardo S, Jos A, Gómez-Amores L, Mate A, Vazquez CM, et al. Antioxidant enzyme activity and lipid peroxidation in liver and kidney of rats exposed to microcystin-LR administered intraperitoneally. Toxicon 2005;45(4):395-402.

18. Aust SD. Lipid peroxidation. In: Greenwald RA, editor. CRC Handbook of Methods for Oxygen Radical Research. Boca Raton, FL: CRC Press; 1985. p. 203-7.

19. Burtis CA, Ashwood ER. Tietz Textbook of Clinical Chemistry. $3^{\text {rd }}$ ed.
Philadelphia, PA: W.B. Saunders Co.; 1999.

20. Singh NP, McCoy MT, Tice RR, Schneider EL. A single technique for quantification of low levels of DNA damage in individual cells. Exp Cell Res 1988;175:184-91.

21. Conners DE. Biomarkes of Oxidative Stress in Fresh Water Clam (Corbicula fluminea) as Mechanistic Tool to Evaluate the Impairment of Stream Ecosystem Health by Lawn Care Pesticides. PhD Thesis. USA: The University of Georgia; 2004.

22. Chen T, Cui J, Liang Y, Xin X, Owen Young D, Chen C, et al. Identification of human liver mitochondrial aldehyde dehydrogenase as a potential target for microcystin-LR. Toxicology 2006;220(1):71-80.

23. da Silva CA, Oba ET, Ramsdorf WA, Magalhães VF, Cestari MM, Oliveira Ribeiro CA, et al. First report about saxitoxins in freshwater fish Hoplias malabaricus through trophic exposure. Toxicon 2011;57(1):141-7.

24. Harada KI. Chemistry and detection of microcystins. In: Watanabe MF, Harada KI, Carmichael WW, Fujiki H, editors. Toxic Microcystis. Boca Raton, FL: Chemical Rubber Company, CRC Press; 1996. p. 103-48.

25. Sicinska P, Bukowska B, Michalowicz J, Duda W. Damage of cell membrane and antioxidative system in human erythrocytes incubated with microcystin-LR in vitro. Toxicon 2006;47(4):387-97.

26. Mitrovic SM, Pflugmacher S, James KJ, Furey A. Anatoxin-a elicits an increase in peroxidase and glutathione S-transferase activity in aquatic plants. Aquat Toxicol 2004;68(2):185-92.

27. Ozturk O, Gumus S. Changes in glucose-6phosphate dehydrogenase, copper, zinc-superoxide dismutase and catalase activities, glutathione and its metabolizing enzymes, and lipid peroxidation in rat erythrocytes with age. Exp Gerontol 2004;39:211-6.

28. van Bladeren PJ. Glutathione conjugation as a bioactivation reaction. Chem Biol Interact 2000;129(1-2):61-76.

29. Campolo J, De Maria R, Caruso R, Accinni R, Turazza F, Parolini M, et al. Blood glutathione as independent marker of lipid peroxidation in heart failure. Int J Cardiol 2007;117:45-50.

30. Li ZH, Zlabek V, Grabic R, Li P, Randak T. Modulation of glutathionerelated antioxidant defense system of fish chronically treated by the fungicide propiconazole. Comp Biochem Physiol C Toxicol Pharmacol 2010;152(3):392-8.

31. Tripathy A. Oxidative stress, reactive oxygen species (ROS) and antioxidative defense system. Int J Curr Res Biosci Plant Biol 2016;3(10):79-89.

32. Cazenave J, Bistoni Mde L, Pesce SF, Wunderlin DA. Differential detoxification and antioxidant response in diverse organs of Corydoras paleatus experimentally exposed to microcystin-RR. Aquat Toxicol 2006;76(1):1-12

33. Galal A, Souich PD. 21-aminosteroids prevent the down-regulation of hepatic cytochrome P450 induced by hypoxia and inflammation in conscious rabbits. Br J Pharmacol 1999;128(2):374-9.

34. Moore MJ, Mitrofanov IV, Valentini SS, Volkov VV, Kurbskiy AV, Zhimbey EN, Eglinton LB, Stegeman JJ. Cytochrome P4501A expression, chemical contaminants and histopathology in roach, goby sturgeon and chemical contaminants in sediments from the Caspian Sea, Lake Balkhash and the Ily River Delta, Kazakhstan. Mar Pollut Bull 2013;46:107-119.

35. Zhang B, Liu Y, Li X. Alteration in the expression of cytochrome P450s (CYP1A1, CYP2E1, and CYP3A11) in the liver of mouse induced by microcystin-LR. Toxins (Basel) 2015;7(4):1102-15.

36. Brooks WP, Codd GA. Immunological and toxicological studies on Microcystis aeruginosa peptide toxin. Br Phycol J 2007;87:22-301.

37. Hudder A, Song W, O'Shea KE, Walsh PJ. Toxicogenomic evaluation of microcystin-LR treated with ultrasonic irradiation. Toxicol Appl Pharmacol 2007;220(3):357-64.

38. Fawell JK, Mitchell RE, Everett DJ, Hill RE. The toxicity of cyanobacterial toxins in the mouse: I microcystin-LR. Hum Exp Toxicol 1999;18(3):162-7.

39. Li X, Ma J, Fang Q, Li Y. Transcription alterations of microRNAs, cytochrome P4501A1 and 3A65, and AhR and PXR in the liver of zebrafish exposed to crude microcystins. Toxicon 2013;73:17-22.

40. Zegura B, Volcic M, Lah TT, Filipic M. Different sensitivities of human colon adenocarcinoma (CaCo-2), astrocytoma (IPDDC-A2) and lymphoblastoid (NCNC) cell lines to microcystin-LR induced reactive oxygen species and DNA damage. Toxicon 2008;52(3):518-25.

41. Nong Q, Komatsu M, IzumoK. Involvement of reactive oxygen species in Microcystin-LR-induced cytogenotoxicity. Free Radic Res 2007;41(12):1326-37.

42. Lankoff A, Banasik A, Obe G. Effect of microcystin LR and cyanobacterial extract from polish reservoir of drinking water on cell 
cycle progression, mitotic spindle, and apoptosis in $\mathrm{CHO}-\mathrm{K} 1$ cells. Toxicol Appl Pharmacol 2004;189(3):204-13.

43. Dias E, Louro H, Pinto M, Santos T, Antunes S, Pereira P, et al. Genotoxicity of microcystin-LR in in vitro and in vivo experimental models. Biomed Res Int 2014;2014:949521.

44. Georg O, Amaeze NH, Soghanmu TO, Otitoloju AA. Biomarkers responses in Tympanotous fuscatus Var. Radula (L) inhibiting an oilimpacted and fire-ravaged mangrove ecosystem, current advance in environmental science. Aman V King Sci Publ 2014;2:101-11.

45. Alodeani EA. Botulinum toxin Type A: An effective, safe and minimally invasive treatment option of axillary and palmar hyperhidrosis. Int $\mathrm{J}$ Pharm Pharm Sci 2016;7:975-1491

46. Ramesh S, Dilipan E, Mayavu P. Effects of drugs against antioxidant and cytotoxic (HEp2 cell line) activity compounds from marine animals conusamadis venom (GMELIN, J.F, 1791). Int J Pharm Pharm Sci 2014;7:975-1491. 